Final version:

Lindgreen, A., Vanhamme, J., Raaij, E. van, and Johnston, W.J. (2013), "Go configure: the mix of purchasing practices to choose for your supply base", California Management Review, Vol. 55, No. 2, pp. 72-96. (ISSN 0008-1256)

For full article, please contact LindgreenA@ cardiff.ac.uk

\title{
Go Configure: The Mix of Purchasing Practices to Choose for Your Supply Base
}

\begin{abstract}
Purchasing and supply management professionals recognize the value of aggressive transactional sourcing, as well as of having cooperative relationships with suppliers. But what mix of transactional and relational purchasing are organizations using, and which should they use? A novel instrument is developed to measure organizations' use of transaction purchasing, electronic purchasing, interactive purchasing, and network purchasing. Four mixes of practices are identified and labeled "transactional," "interpersonal dyadic," "interpersonal network," and "integrative relational" configurations. Organizations using an integrative relational configuration generally outperform others. Irrespective of configuration, organizations use more interactive and network purchasing with suppliers of direct inputs but more transaction purchasing with suppliers of indirect inputs.
\end{abstract}


Some 25 years ago, a purchasing and supply management revolution took place in North America and Western Europe. With it came a change in supplier relationships. No longer were these relationships only adversarial and arm's-length, many of those became instead much closer and more cooperative, ${ }^{\mathrm{i}}$ and often embedded in a wider network of suppliers and their suppliers, customers and their customers, and other stakeholders. ${ }^{\text {ii }}$ The role of purchasing and supply management, as a business function, is to manage the organization's external resources and acquire inputs by the best means possible. ${ }^{\text {iii }}$ Traditionally, purchasing has revolved around single transactions or short-term contracts, with much of the emphasis being on low price. ${ }^{\text {iv }}$ But manufacturing organizations typically spend 50-75 percent of their revenues on purchasing materials and services, ${ }^{\mathrm{v}}$ and by the late $1990 \mathrm{~s}$, a growing need to improve quality and reduce costs in the face of international competition ${ }^{\mathrm{vi}}$ had led organizations to realize that purchasing and supply management offered enormous potential for more strategic management of costs, risks, and value. ${ }^{\text {vii }}$

North America and Western Europe thus looked for inspiration to countries like Japan, where cooperative supplier relationships had been common practice since the 1960s. ${ }^{\text {vii }}$ Organizations such as Chrysler, Sony, Toyota, and Xerox reduced the number of suppliers for their components and raw materials, ${ }^{\mathrm{ix}}$ and their remaining supplier relationships became more cooperative and relational. ${ }^{\mathrm{x}}$ In transactional exchanges the buying organization and its supplier treat each other as adversaries in a zero-sum game, with no expectation of exchange beyond the current contract. By contrast, the new relational exchanges push the buying organization and its supplier to work together to increase mutual benefits, make dedicated investments, and develop expectations beyond the contract terms. ${ }^{\mathrm{xi}}$ This shift toward more relational purchasing practices coincided with the emergence of a more strategic role for purchasing, which required purchasing managers to rely more on integrative partnerships with a limited number of key suppliers. ${ }^{\text {xii }}$ 
Existing studies have assumed purchasing practices ${ }^{\text {xii }}$ are either transactional or relational. ${ }^{\text {xiv }}$ Purchasing today, however, involves both transactional and relational practices, ${ }^{\mathrm{xv}}$ often through a mix of arm's-length transactional relationships and close cooperative relationships with suppliers. ${ }^{\mathrm{xvi}}$ Relational exchanges have attracted significant attention from academia in areas such as transaction cost economics, sociological approaches, and supply chain management, ${ }^{\text {xvii }}$ and research has highlighted the advantages of cooperative relationships with suppliers. These can include, for example, reduced costs, improved product quality, and reduced lead times. ${ }^{\text {xiii }}$ Yet cooperative relationships remain costly to manage and increase the buyer's dependence on the supplier. ${ }^{\text {xix }}$ Such relationships may therefore not be applicable in all situations. Because buyers engage in both transactional and relational purchasing, it is vital to understand more about how and why they decide which approach to take. That is, how do buyers choose, or mix, different purchasing practices, and how do different purchasing practices affect organizations' performance? ${ }^{\mathrm{xx}}$

Evaluating how a specific choice of supply relationships relates to an organization's performance is only possible if the organization can measure the type and strength of its purchasing relationships and then judge those relationships against specific performance indicators. Managers thus need a toolbox.

For marketing practices, for example, a toolbox has led to a better awareness of "how firms relate to their [customer] markets in a manner that integrates both traditional and more modern views of marketing, and incorporates an understanding of both the antecedents and consequences of different practices."xxi This also includes an understanding of the role played by marketing. The marketing toolbox presents managers with a robust and well-tested way of evaluating what they are doing, using indicators based on the exchange and managerial aspects of marketing practices. ${ }^{\text {xii }}$ 
Building a toolbox for purchasing requires purchasing to be categorized into transactional and relational practices. This article puts forward a new framework and a novel measurement instrument. What this proposed framework does in particular is:

- to identify fundamental aspects that distinguish different types of purchasing practices, especially those related to the exchange and management of purchasing rather than those related to differences in the purchasing function itself; ${ }^{x x i i}$

- to assess what different hybrid forms, or mixes, of transactional and relational purchasing are being used; and

- to relate the way in which purchasing is practiced to performance outcomes.

The framework addresses a range of important questions. What relative emphasis do organizations place on transactional and relational aspects of purchasing? Does relational purchasing occur across all types of organizations? Do organizations practice either transactional or relational purchasing, or is there a hybrid form that is more appropriate? Do purchasing practices depend on the materials and services being supplied? Are higher performance outcomes correlated with particular (mixes of) purchasing practices?

The proposed framework characterizes the key aspects of different purchasing practices, and has been used to examine the actual purchasing practices of 202 U.S. organizations and what influence those practices have on performance outcomes. The framework captures the exchange and managerial aspects of purchasing, as they relate to four types of purchasing practices.

\section{THE PURCHASING PRACTICES FRAMEWORK}

\section{Design of the Purchasing Practices Framework}

One important distinction is between a supply management approach that is primarily transactional and one that emphasizes network coordination, including the supply chain. ${ }^{\text {xiv }}$ Thus transaction purchasing refers to the use of aggressive sourcing (continuously searching 
for new suppliers) to obtain goods and services on the best terms possible, ${ }^{\mathrm{xxv}}$ whereas network purchasing involves positioning the organization within a wider organizational system or network. ${ }^{\text {xvi }}$ Two additional practices are possible: electronic purchasing ${ }^{\text {xxvii }}$ and interactive purchasing. ${ }^{\text {xxiii }}$ With electronic purchasing, organizations use the Internet and other one-to-one and one-to-many technologies to create and mediate data exchanges with suppliers; and interactive purchasing implies personal interactions between employees and individual suppliers.

It is important to note here that electronic purchasing as an approach to supplier management is not the same as electronic procurement. Electronic procurement refers to the collection of tools - usually based on Internet technology-that support the purchasing function. Examples might include electronic auctions, marketplaces, or ordering systems. ${ }^{\text {xix }}$ But electronic auctions, for example, cannot serve as relationship management tools; they imply aggressive sourcing, or transaction purchasing. ${ }^{\mathrm{xx}}$ In contrast, electronic purchasing as defined here uses the Internet and other information technologies as a means of facilitating relationships with suppliers, ${ }^{\text {xxxi }}$ for example by using a supplier portal.

As reflected in the framework, all four purchasing practices are significantly different to one another in how the buying organization manages its exchange relationships with suppliers and interacts with them. For example, both the frequency of communication and the nature of the interdependency between an organization and its suppliers differ between transaction purchasing and the three relational purchasing practices (electronic purchasing, interactive purchasing, and network purchasing). Likewise there are also differences among those relational purchasing practices themselves. ${ }^{\text {xxxii }}$

The proposed measurement instrument aims to investigate purchasing practices across a wide range of organizations and industry sectors. The measures used must therefore be general enough to have relevance across that range, yet the positions should also be specific 
enough to capture different practices of purchasing. Eight formative indicators are used to characterize transactional and relational practices, as summarized briefly in Table 1 and defined in more detail below; each purchasing practice can be determined by a combination of these formative indicators. Table 1 also includes a general indicator that captures the essence of each purchasing practice (and which is used when testing the external validity of the measuring instrument, see later in Exhibit 1).

Insert Table 1 about here

Purpose of exchange. In relational purchasing, buying organizations develop closer and more collaborative relationships with a smaller number of suppliers. ${ }^{\text {xxiii }}$ In each of the three forms of relational purchasing practices the aims are slightly different. In electronic purchasing it is about developing relationships that are facilitated by electronic data interchange systems; ${ }^{\text {xxxiv }}$ for interactive purchasing, it is to develop interpersonal relationships with suppliers; ${ }^{\mathrm{xxv}}$ and in network purchasing, it is to develop relationships with all relevant parties in the wider organizational network. ${ }^{\text {xxvi }}$ Transaction purchasing is different again: here the aim is to obtain competitively priced components and raw materials and achieve cost savings through competitive bidding among many suppliers. ${ }^{\text {xxxvii }}$

Nature of communication. Although organizations with transaction purchasing interact with many suppliers and tend to use one-fits-all communication, ${ }^{\text {xxxviii }}$ organizations that use relational practices reduce the size of their supply base and communicate more-at different levels, and in more complex relationships-with the suppliers that remain. ${ }^{\text {xxxix }}$ This can include technology-enabled communications in electronic purchasing, ${ }^{\mathrm{xl}}$ personal interactions in interactive purchasing, ${ }^{x l i}$ and senior managers interacting across organizations in network purchasing. ${ }^{\text {xlii }}$

Type of contact. Whereas transaction purchasing uses short-term, arm's-length relationships, relational purchasing involves longer-term, collaborative relationships. These 
are often at a strategic level, with a wider range of business partners. ${ }^{\text {xliii }}$ Thus, transaction purchasing is characterized by impersonal contact, whereas relational purchasing is characterized by technology-enabled, interactive contact in electronic purchasing, interpersonal contact in interactive purchasing, and inter-organizational contact across organizations in a wider network in network purchasing. ${ }^{\text {xliv }}$

Duration of exchange. Transaction purchasing has a focus on a single transaction or contract, ${ }^{\mathrm{xlv}}$ whereas relational purchasing focuses on an ongoing interaction, whether that is technology-based in electronic purchasing, interpersonal in interactive purchasing, or across a wider organizational network of purchasing relationships in network purchasing. ${ }^{\text {xlvi }}$

Formality of exchange. Organizations with an arm's-length approach to purchasing limit their exchanges with suppliers to formal modes. The relational approaches, on the other hand, combine formal and informal modes, such that organizations become embedded in social interactions and networks. ${ }^{\text {xlvii }}$

Managerial intent. Relational purchasing attempts to create technology-enabled exchanges with suppliers in electronic purchasing, build interpersonal relationships with specific suppliers in interactive purchasing, and coordinate activities in the purchasing network in network purchasing. ${ }^{\text {xlviii }}$ This is very different to transaction purchasing, where organizations continuously search for new suppliers in order to find the best deal. ${ }^{\text {xlix }}$

Managerial focus. Whereas transaction purchasing is preoccupied with purchase items and prices, ${ }^{1}$ managing IT-enabled relationships with suppliers represents the heart of electronic purchasing, including automated data input and electronic data interchange between buyers and suppliers. ${ }^{\text {li }}$ The relationships are fewer in number but more individualized in both interactive purchasing and network purchasing, and the latter includes relationships with partners from the organization's wider purchasing and supply network. ${ }^{\text {lii }}$ 
Managerial investment. An organization that is pursuing relational purchasing invests significant and specialized resources to attract, develop, and retain strategic supplier relationships. ${ }^{\text {lii }}$ The investments and resources involved include information and communication technologies in electronic purchasing, personal relationships in interactive purchasing, and network relationships in network purchasing. ${ }^{\text {liv }}$ In contrast, to obtain lower prices from suppliers, an organization that uses transaction purchasing invests resources in specifying components and raw materials, as well as in negotiating, ordering, and expedition activities. $^{\text {lv }}$

The proposed purchasing practices framework enables an organization to score high, for example, on both transaction purchasing and electronic purchasing and low on the other two practices, or perhaps to score low on transaction purchasing and high on all three forms of relational purchasing practices. That is, the four practices of purchasing are not mutually exclusive. Frameworks that describe the organizational management of supplier relationships only as either type A or type B may fail to recognize all existing types of supplier relationships. For example, some organizations continuously search for new suppliers to find the best deal, whereas others believe that they can add value to their supplier relationships by combining that type of practice with relational practices, for example technologies that allow the organization to exchange data with suppliers and develop one-to-one relationships.

\section{Surveying Organizations' Purchasing Practices}

To get a better understanding of organizations' purchasing practices, this study used a nationwide survey of purchasing managers in U.S. organizations. The survey was based on the proposed purchasing practices framework. From its databases, the Institute of Supply Management (ISM) provided contact details for 3,322 randomly selected members representing manufacturing, wholesaling and retailing, and service organizations (standard industrial classification codes: 20-39, 52-59, and 70-89). All respondents were contacted by 
regular mail; the packets contained a copy of the questionnaire (including the purchasing practices framework), a cover letter, a letter from ISM endorsing the study, and a pre-paid return envelope. Respondents could either return their completed questionnaire by mail or fill out an online version. This procedure produced 202 valid returned questionnaires. ${ }^{\text {lvi }}$ It should be noted that the respondent sampling includes only ISM members, who are fairly representative of U.S. organizations but might be relatively well-educated purchasing professionals, ${ }^{\text {lvii }}$ and that for each organization only one individual was asked to complete and return the questionnaire.

The questionnaire consisted of six parts (see Appendix A). In the first part, respondents provided details of their organization, the degree to which technology was used in the organization and the part played by information technology. These questions recognize that technology is an important driver of change in the purchasing domain. ${ }^{\text {lvii }}$ All measures in this part of the questionnaire were taken from previous studies. ${ }^{\text {lix }}$

In the second part of the questionnaire, respondents were asked to distinguish between suppliers of direct inputs (or "primary suppliers") and suppliers of indirect inputs (or "secondary suppliers"). Direct inputs are those materials and services that appear in the buying organization's final products or services such as wood for furniture; indirect inputs are those which do not, for example, office stationery. ${ }^{\mathrm{lx}}$ Direct inputs are also known as revenue-generating, primary, or bill-of-materials inputs. Respondents also described the kinds of materials and services supplied by these direct and indirect suppliers, which helped them distinguish between the two types when answering questions about their organizations' purchasing practices. By making this distinction between relationships with suppliers of direct versus indirect inputs (not purchasing practices at the individual supplier level), this study is able to look at a broad range of organizations, and provides rich information (i.e., there is more variance at the organizational level than at the individual level ${ }^{\mathrm{lxi}}$ ). It also 
ensures minimal respondent subjective bias. That is, one can distinguish relatively objectively between suppliers of direct and indirect input, which is not the case when asked to concentrate on "key" or "strategic" suppliers. 1xii

In the third and fourth parts of the questionnaire, respondents reported on their organizations' purchasing practices with direct and indirect suppliers. For suppliers of direct materials and services, 32 indicators reflected the eight exchange and managerial aspects of the purchasing practices (i.e., the framework), and 4 global indicators represented general descriptions of each practice (Table 1). For each of these 36 indicators, respondents indicated the extent to which it was currently practiced in their organization. ${ }^{\text {xiii }}$ For suppliers of indirect materials and services, they were asked only about how the organization generally dealt with the suppliers, and only the 4 global indicators were used so as to ensure the questionnaire did not become too long.

The fifth part involved looking at three areas. Firstly, the organization's purchasing performance relative to its expectations about supplier lead time, on-time delivery, delivery reliability, and quality. ${ }^{\text {lxiv }}$ Secondly, its marketing performance relative to expectations with regard to customer attraction and retention, customer satisfaction, sales growth, and market share. Thirdly, its financial performance in terms of its expectations with regard to profitability. $^{1 \mathrm{xv}}$

Finally, to judge whether the respondents provided an appropriate match for the study, the questionnaire solicited their personal data, including their position, how long they have held their current position, their tenure with the organization, and their formal purchasing qualifications or training. It also asked for gender and age information, consistent with previous studies of marketing practices and purchasing. ${ }^{\text {lxvi }}$

Table 2 provides an overview of the types of organizations and respondents within the study. Respondents from manufacturing, wholesaling and retailing, and services were well 
represented in the sample. Almost two-thirds of respondents came from large organizations (more than 500 employees). Sixty-five percent of the organizations were established more than 30 years ago, and most relied on a domestic market for their sales.

\section{Insert Table 2 about here}

Because the vast majority of respondents hold positions in purchasing and at middle and upper levels in their organization, they probably have experience, knowledge of management policies, and access to operational and quality performance data. ${ }^{1 x v i i}$ With regard to marketing and financial performance outcomes, if respondents felt that they did not know the answer, the questionnaire encouraged them to seek this information from the appropriate departments. ${ }^{\text {lxviii }}$ The average age of respondents was 47 years (minimum 21; maximum 66). The gender ratio was $57 \%$ men to $40 \%$ women; $3 \%$ left this question unanswered. The data quality assessment and the psychometric properties (including a validity assessment) of the purchasing practices measurement instrument involved several checks, as reported in Appendix B.

For each of the four purchasing practices (transaction purchasing, electronic purchasing, interactive purchasing, and network purchasing) the organization was scored against eight indicators (purpose of exchange, managerial intent, nature of communication, type of contact, duration of exchange relationship, formality of exchange, managerial focus, and managerial investment). The total score on all eight indicators for each practice was then converted into an index. ${ }^{\text {lxix }}$ For each organization, four composite measures thus indicate the extent to which that organization practices transaction purchasing, electronic purchasing, interactive purchasing, and network purchasing. However, because these practices are not mutually exclusive, ${ }^{\mathrm{lxx}}$ each organization has its own particular mix of scores on the four purchasing practices.

Major Configurations of Purchasing Practices 
Purchasing literature suggests that organizations traditionally practiced transactional purchasing but that relational practices have become more commonplace. ${ }^{\text {lxi }}$ Not all organizations have made the transition to relational purchasing, however. ${ }^{\text {lxii }}$ In reality, transactional and relational purchasing are not mutually exclusive and can be mixed in hybrid configurations. To reveal what kinds of configuration might be particularly common, this study incorporated a cluster analysis - described in more detail in Exhibit 1-of the index scores to determine whether it is possible to identify meaningful groups of organizations in terms of their purchasing practices.

\section{Exhibit 1 Cluster analysis}

Before doing a cluster analysis, one needs to confirm that different variables do not suffer from substantial collinearity, ${ }^{\text {lxxii }}$ which would act as a weighting factor and bias the analysis (i.e., collinear variables are implicitly weighted more heavily ${ }^{\text {lxxiv }}$ ). The next step entails row centering the data to identify groups according to the relative importance of one construct (purchasing practice) to another and determine whether clusters with similar patterns can be identified. The hierarchical and nonhierarchical clustering methods are used sequentially to increase the validity of the solution. ${ }^{\text {lxx }}$ Using Ward's hierarchical method and the recommended squared Euclidean distance, the most meaningful number of clusters was established and allowed a check of potential outliers. ${ }^{\text {lxxi }}$ Ward's method offers robustness, the ability to maximize within-cluster homogeneity and between-cluster heterogeneity, and the capability to recover known cluster structures.

No outliers emerged, so to determine the most appropriate number of clusters, ${ }^{\text {lxxvii }}$ several steps were taken. The likely range of clusters was computed, ${ }^{\text {lxviii }}$ a dendogram was used to find any relatively dense branches, ${ }^{\text {lxxix }}$ and incremental changes in the agglomeration coefficient were analyzed. ${ }^{\mathrm{lxx}}$ Finally, managerial interpretability of the solution was sought. ${ }^{\text {lxxxi }}$ 
The analysis reveals four distinct clusters of organizations that differ markedly in their emphasis on the different purchasing practices (transaction purchasing, electronic purchasing, interactive purchasing, and network purchasing) and are easily interpretable and meaningful. A nonhierarchical K-means clustering method (with the cluster centers provided by the hierarchical results as initial seed points) fine-tunes these results, in a way less susceptible to outliers, the type of distance measure, or the inclusion of irrelevant and inappropriate variables in the analysis. ${ }^{\text {lxxii }}$ The results from the K-means clustering (i.e., the final results) are very similar to the previous results and are presented in Table 3.

Insert Table 3 about here

One cluster consists of organizations that score high on the transaction purchasing index and low on electronic purchasing, interactive purchasing, and network purchasing (see Figure 1). This mix is labeled as a transactional configuration. Another cluster consists of organizations that score low on the transaction purchasing index and high on the electronic, interactive, and network purchasing indexes. This mix is labeled as an integrative relational configuration.

Two additional clusters are identified. Organizations in these two clusters achieve medium scores on the transaction purchasing index. The first configuration-labeled as interpersonal dyadic configuration - shows a high score on the interactive purchasing index but lower scores on the electronic purchasing and network purchasing indices. The second of these configurations-labeled as interpersonal network configuration-has a high score on both interactive purchasing and network purchasing but a low score on the electronic purchasing index.

The transactional configuration and the integrative relational configuration could, more or less, be seen as opposites of each other. With their medium scores on the transaction 
purchasing index, the interpersonal dyadic and the interpersonal network configurations could be regarded as intermediate ones.

Notably, relationships mediated by the Internet and other interactive technologies (i.e., electronic purchasing) reach high levels only when combined with the other two relational purchasing practices (i.e., interactive purchasing and network purchasing). In none of the clusters does network purchasing exceed interactive purchasing. Overall, in many organizations purchasing practices are pluralistic, with organizations mixing two or more different purchasing practices.

\section{Insert Figure 1 about here}

\section{So Which Mix of Purchasing Practices Should You Choose for Your Supply Base?}

The purchasing practices framework has revealed different configurations that vary in their relational intensity. Several positive effects of relational purchasing practices appear in prior literature, often relating to the enhanced performance of suppliers and buyers. With organizations spending up to 75 percent of their revenues on purchasing, the performance of the buying organization depends increasingly on supplier performance. ${ }^{\text {lxxiii }}$ A relational practice has positive effects on supplier quality, delivery reliability, lead time, and on-time delivery, as well as on the delivery- and quality-related performance of the buying organization itself. It also has effects on buyer performance in terms of cost- and flexibility. ${ }^{\text {lxxiv }}$ Improvements in cost-, quality-, and delivery-related performance as a result of close buyer-supplier relations also should enable a buying organization to serve its customers better with higher-value products and improved customer service. ${ }^{\text {lxxv }}$ Where an organization can deliver distinctive value to customers that should translate into better market performance. ${ }^{\text {lxxvi }}$ Ultimately, such advantages in market and cost performance should lead, in turn, to higher financial performance by the buying organization. lxxxvii $^{\text {in }}$ 
The findings of our study reveal that those organizations that have adopted an integrative relational configuration for their purchasing practices show the best performance. Figure 2 shows the comparison of the three clusters of organizations with transactional, interpersonal dyadic, and interpersonal network configurations with the cluster of organizations with an integrative relational configuration. This comparison highlights that the latter cluster performs better than any other cluster on the dimension of supplier quality. In terms of delivery reliability, organizations with an integrative relational configuration perform significantly better than those with a transactional configuration, but there is no significant difference between organizations with an integrative relational configuration and those with intermediate configurations. The integrative relational configuration outperforms the transactional configuration on supplier on-time delivery, but the performance differences with the two intermediate configurations are not significant. The four configurations are broadly comparable in terms of supplier lead time. With respect to marketing performance outcomes, the integrative relational configuration performs better than all other configurations for all marketing performance outcomes: customer attraction and retention, customer satisfaction, sales growth, and market share. This finding also applies to the financial performance outcome: profitability. ${ }^{1 x x x v i i i}$

\section{Insert Figure 2 about here}

Thus, organizations using all three forms of relational purchasing practices (i.e., integrative relational configuration) perform better on at least seven but up to nine out of 10 performance outcomes compared with organizations that favor practices that are less relational (i.e., interpersonal dyadic, interpersonal network, and transactional configurations). This finding is true for all marketing and financial outcomes and up to three purchasing performance outcomes (Figure 2). 
No significant differences were found across clusters in terms of the organizational demographics of cluster members (i.e., industry, organization size, age, and business activities). Some differences appeared in terms of the level of technology intensity and the role of technology in the organization. Organizations with an integrative relational configuration tend to be more technology-intensive than those with other configurations, and the role of information technology in the former organizations appears greater than in the latter organizations. For organizations with an integrative relational configuration, information technology acts not just to support current business activities but rather to redefine or drive such activities. ${ }^{\text {lxxix }}$

\section{Different Purchasing Practices in Relation to Direct and Indirect Suppliers}

The survey results indicate that — across all clusters — organizations practice more relational purchasing with direct suppliers, and more transactional purchasing with indirect suppliers (Figure 3). When dealing with direct suppliers, organizations make significantly more use of interactive purchasing and network purchasing than they do with indirect suppliers. In contrast, with indirect suppliers they use significantly more transaction purchasing than they do with direct suppliers. There was, however, no marked difference with respect to electronic purchasing. ${ }^{\mathrm{xc}}$

Insert Figure 3 about here

\section{DISCUSSION}

The data indicate four configurations of purchasing practices, each characterized by a distinct mix of transaction purchasing, electronic purchasing, interactive purchasing, and network purchasing. Organizations with a transactional configuration (19\% of the sample) and those with an integrative relational configuration (29\%) generally represent the most extreme configurations. In between, intermediate configurations of practices are based on interpersonal relationships, either dyadic (26\%) or network (26\%). The emphasis on 
transaction purchasing, electronic purchasing, interactive purchasing, and network purchasing varies across configurations. Whereas interactive purchasing (based on interpersonal relationships) is pervasive and used to a great extent in all but the transactional configuration, transaction purchasing levels are generally medium to high, and used in all but the integrative relational configuration.

Thus, buying organizations manage portfolios of supplier relationships, some of which are more transactional in nature and others more relational. Transactional purchasing is not disappearing entirely, even as buying organizations move to more relational practices. Focusing solely on just two possible purchasing practices - pure transactional practice versus pure relational practice-is thus too simple a view of reality. ${ }^{\text {xci }}$ It also obscures performance outcome differences that reflect an organization's emphasis on particular mixes of purchasing practices. The integrative relational configuration outperforms all other configurations on the marketing and financial performance indicators, as well as on supplier quality. It also outperforms the transactional configuration on delivery reliability and supplier on-time delivery.

Purchasing practices relate to the type of supplier, such that more relational practices characterize relationships with direct suppliers, whereas more transactional practices are more common in dealing with indirect suppliers. Quality or delivery problems with direct suppliers could result in disruptions to the buying organization's primary processes, so organizations often strive for close, cooperative relationships with critical direct suppliers. In contrast, the purchase of indirect materials and services receives far less management attention; the purchasing department may not even be involved in these purchases. Indirect supply purchases more often involve arm's-length transactions. Because indirect suppliers also lack critical relationships with the buying organization, the organizations may perceive less risk in letting price play a more dominant role when selecting this type of supplier. That 
is, they practice more transaction purchasing. ${ }^{x c i i}$ Discussions with experienced purchasing professionals and academics confirm that when organizations purchase from secondary suppliers of indirect inputs, cost considerations are the most important factors. For primary suppliers of direct inputs, other factors, including supplier lead time, on-time delivery, delivery reliability, and quality, acquire greater importance.

Which organization selects which configuration cannot be explained by its size, age, or business activities. This finding contradicts what contingency theory suggests—namely, that the best approach to purchasing (relational or transactional) depends on the organizational context. Organizations are likely to make strategic choices regarding whether to focus on transactional or relational purchasing practices. However, respondents in the integrative relational configuration report that the intensity of information technology in their organizations is high and that they use information technology to redefine their business processes. These responses coincide with the finding that the main difference between the integrative relational configuration and the other configurations is that those in that first group make extensive use of electronic purchasing. To redefine an organization by extending its boundaries ${ }^{\mathrm{xciii}}$ and to build, enhance, sustain, and align relationships with suppliers, customers, and other partners, strategic investments in information technologies appear necessary. This is because the involvement of partners enables organizations to market new products and services, gain operational efficiencies, and enhance revenues, amongst other. ${ }^{\text {xciv }}$ Especially when an organization has a complex manufacturing system, detailed interfaces with partners, and a dynamic market environment, information technologies may effectively enable that organization to develop, alter, and strengthen its relationships with partners in its purchasing system. ${ }^{\mathrm{xcv}}$

Organizations that employ interactive purchasing use this alone or they combine it with either electronic purchasing or network purchasing. This observation supports arguments that 
suggest the primary feature of a relational practice is the level of trust between the buyer and supplier. Trust previously has been identified a key role in building successful personal interactions between employees and individual suppliers, ${ }^{\mathrm{xcvi}}$ as well as in managing risks in an organization's supply base. ${ }^{\text {xcvii }}$

\section{Managerial Implications}

Perhaps the key finding for managerial practice is how organizations with an integrative relational configuration performed significantly better than did organizations with other configurations. This was true on a variety of purchasing, marketing, and financial performance measures. The value-creation potential of purchasing and supply management has been noted before; the current study emphasizes the need to view purchasing and supply management as a strategic function that is internally aligned and integrated with other functions. ${ }^{\text {xcviii }}$ Organizations thus may find it more profitable to encourage mutual understanding and effective collaboration between marketing and purchasing; integrate technology-based interactions with suppliers; invest in interpersonal relationships across suppliers and the broader purchasing network; and consciously manage the marketingpurchasing interface.

In particular, the purchasing practices framework, depicted as a radar diagram (Figure 1), could be used as a form of scorecard. It provides a simple, easily accessible means to track and monitor the implementation of a purchasing configuration. For this study, the diagrams depict how four clusters of organizations compare in terms of the mixes of purchasing practices they employ. Each respondent answered the questions included in our measurement instrument (or 'toolbox') for all direct suppliers of his or her organization

An individual organization could use the same measurement instrument in a slightly different way, asking each of its buyers to answer questions about the suppliers that they manage. All data for each purchasing practice (transaction purchasing, electronic purchasing, 
interactive purchasing, network purchasing) then could be aggregated into single scores. Therefore, for each buyer, there would be four scores - one per purchasing practice - that managers could plot on a buyer-specific radar diagram. On a different level, buyers often manage several purchasing categories (e.g., electronic components, spare parts, temporary labor, office supplies), so an organization could ask its buyers to answer questions for each purchasing category that they manage, then plot radar diagrams to compare how purchasing categories are managed. Similarly, a multi-unit business organization could plot and compare how business units manage (parts of) their supply base.

Applying the measurement instrument on these various levels requires that the questions be reworded slightly to make them applicable to the buyer, category, or business unit level. For example, in this study the measurement instrument asks how purchasing is practiced in a particular organization with its direct suppliers (see Table 1); this item could be reworded to query, "How is purchasing practiced when you deal with your suppliers?" (buyer level), "How is purchasing practiced with your suppliers of product category A?" (category level), or "How is purchasing practiced in your business unit with direct suppliers?" (business unit level). Other questions in the survey may need similar slight rewording, to reflect the level at which the survey takes place.

The four aggregate scores of purchasing practice — at the buyer, category, or business unit level — can be used to perform a cluster analysis, especially if the number of buyers, categories, or business units is large. ${ }^{\text {xcix }}$ Although the number of buyers or business units may be limited in any one organization, such that radar diagrams can be constructed for each, organizations typically manage so many purchasing categories that clustering becomes opportune. ${ }^{\mathrm{c}}$ With the four scores, managers can devise a radar diagram per cluster, which in this case depicts how much of each purchasing practice gets used per cluster. The performance outcomes also could be evaluated per cluster. 
A radar diagram of this kind then could be leveraged with target achievement levels. The gap between actual and target levels forms the basis for a focused discussion about how to bridge the gap. Over-achievement similarly could spark a discussion about whether some resources might be allocated more usefully elsewhere. Thus, the purchasing practices framework can help organizations track, monitor, and assess their purchasing practices across buyers, purchasing categories, and business units; it also can help determine the most appropriate configurations of purchasing practices to pursue.

With this performance outcome data on hand, organizations can specify their strategies, as depicted in Figure 4. Managers can make informed decisions about the organization's relations with groups of suppliers. Objectives, in terms of purchasing practices and performance outcomes, result from the strategy specification.

The next step involves tracking, monitoring, and evaluating purchasing practices, just as managers did when mapping the current situation. Finally, managers can reassess their strategy and take corrective action (strategy re-specification) if necessary. The process shown in Figure 4 should be repeated periodically.

Insert Figure 4 about here

For analyzing purchasing practices at the industry level, the process is similar, except that further distinctions are necessary to assess the purchasing practices indicators, such as distinguishing direct from indirect suppliers or any other variable of interest. The supplier clustering then should be run separately for the chosen variables of interest, and the remaining steps of the process should be revised accordingly. An analysis at the industry level is likely to be carried out by groups, such as chambers of commerce, consulting companies, or industry representatives.

\section{Further Research}


Conventional wisdom suggests that the emphasis in purchasing is increasingly on relational aspects; ${ }^{\mathrm{ci}}$ this study shows that an integrative relational configuration is also synonymous with increased performance. Yet the results indicate that when dealing with suppliers of direct inputs, almost a fifth of organizations still practice transactional purchasing. Are purchasing managers unaware of the performance implications of relational purchasing, or are these types of practices difficult to implement, perhaps because global sourcing initiatives have increased the physical distance between buyer and supplier? ${ }^{\text {cii }}$ To help uncover the drivers behind purchasing practices, further research should investigate when and why transactional and relational purchasing, and their different combinations, exist. If such research also predicted causal relationships, it would be possible to use structural equation models to achieve both the validation of the measures and the estimation of causal relationships. The use of structural equation models also would enable further fine tuning of the purchasing practices measurement instrument.

Further research could seek to adapt the instrument so that — within one organization - the type of practices used in relation to individual suppliers (i.e., one level lower than the buyer level) could be measured more easily. The instrument would need to be revised, to address the questions that are not suitable for the individual level (e.g., questions $7 \mathrm{a}$ and $7 \mathrm{~b}$ in part 3 of the measurement instrument), and then validated.

This study has revealed four configurations of purchasing practices. No claims, however, are made as to whether the interpersonal dyadic configuration (that makes high use of the relational interactive purchasing practice) and interpersonal network configuration (that makes high use of the two relational interactive and network purchasing practices) are merely transition states toward the integrative relational configuration (that makes high use of all three relational purchasing practices). Using a longitudinal design, ${ }^{\text {iii }}$ further research could capture the evolutionary patterns of purchasing practices, which would enhance greatly our 
knowledge of how relationships develop. ${ }^{\text {civ }}$ Longitudinal research also might help to determine whether purchasing develops progressively along a transactional-relational purchasing continuum (from the transactional configurations, via the interpersonal dyadic and the interpersonal network configurations, to the integrative relational configuration) or whether it can move in either direction. ${ }^{\mathrm{cv}}$ For example, instead of traveling in a linear fashion through the four purchasing configurations, organizations may in fact employ any one at any given time, depending which specific mix of practices is felt to be most strategically advantageous. Examining the path-dependent nature of purchasing practices-that is, differences in the past lead to different purchasing practices in the future ${ }^{\text {cvi }}$-also could reveal the route that organizations follow to integrate their purchasing practices with suppliers. ${ }^{\text {cvii }}$

In conclusion, it is noteworthy that this study has provided significant findings regarding the measurement of purchasing practices. Additional fine tuning, using larger samples, could continue to improve the way purchasing practices are being measured. 
Part 1

\section{Appendix A: Survey of Purchasing Practices}

1. Which statement(s) describes your organization's business activities?

Choice categories were: Retailing / wholesaling / dealing; Production of industrial equipment and durable goods (e.g., manufacturing equipment); Production of industrial components (e.g., memory chips, semi-manufactured goods); Production of industrial materials and consumables (e.g., energy, office stationery); Production of consumer durable goods (e.g., automobiles, household appliances); Production of consumer-packaged goods / fast-moving consumer goods (e.g., detergents, pet food); Provider of business-to-business services (e.g., management consulting); Provider of consumer services (e.g., retail banking); Not-for-profit organization; Other (please specify).

2. Was your organization established....:

Choice categories ranged from less than 2 to more than 30 years

3. Would you describe your organization as....
a low-technology organization
12
45 a high-technology organization

4. What role does information technology play in your organization?

Choice categories were: Reinforces and preserves the status quo (i.e., information technology is used to support our current business activities); Enhances the status quo (i.e., information technology is used to extend / improve our existing business activities); Transforms the status quo (i.e., information technology is used to redefine / drive our business activities)

5. How many people are currently employed in....

a) your organization?

b) purchasing activities?

Choice categories ranged from less than 25 to 500 or more

6. Is your organization...:

Choice categories were: a strategic business unit in a larger organization; a division in a larger organization; a plant in a larger organization; a subsidiary of a larger organization; an independent entity; other (please specify)

Part 2

In the following section a distinction is made between suppliers of product-related items (which are used in your organization's main production, for example wood for furniture) and suppliers of nonproduct-related items (which are not used in your organization's main production, for example office stationery).

1. Please describe the type of products and services supplied by your organization's suppliers of product-related items (i.e., your primary suppliers).

2. Please describe the type of products and services supplied by your organization's suppliers of nonproduct related items (i.e., your secondary suppliers).

\section{Part 3}

This section has questions about how purchasing is practiced in your organization with your primary suppliers (i.e., suppliers of product-related items).

Please answer all parts of each question by circling the number that best corresponds to what actually happens in your organization. The scale is a 5-point scale with 1 for 'never' and 5 for 'always.'

1. Our purchasing activities are intended to:

a) continuously search for new suppliers to find the best deal (i.e., low prices)

b) create two-way, technology-enabled data exchange with our suppliers

c) develop cooperative relationships with our suppliers

d) coordinate activities between ourselves, suppliers, and other parties in our wider purchasing system (e.g., second-tier suppliers, key customers, service providers, and other organizations with which we interact through our purchasing activities)

2. Our purchasing strategy is focused on issues related to:

a) the purchase item and its price

b) managing IT-enabled relationships with many individual suppliers 
c) one-to-one relationships with suppliers, or individuals in supplier organizations we deal with

d) the network of relationships between individuals and organizations in our wider supply system

3. When dealing with our primary supply market(s), our purpose is to:

a) achieve cost savings or other 'financial' measure(s) of performance (monetary transactions)

b) create information-generating dialogue with many identified suppliers

c) build a long-term relationship with specific supplier(s)

d) form relationships with a number of organizations in our supply market(s) or wider purchasing system

4. Our organization's contact with our primary suppliers is:

a) arms-length, impersonal with no individualized or personal contact

b) interactive via technology such as the Internet

c) interpersonal (e.g., involving one-to-one interaction between people)

d) across firms in the broader network (from impersonal to interpersonal contact)

5. The type of relationship with our primary suppliers is characterized as:

a) transactions that are discrete or one-off (i.e., not ongoing)

b) technology-based interactivity that is ongoing and real-time

c) interpersonal interaction that is ongoing

d) contact with people in our organization and wider purchasing system that is ongoing

6. Our purchasing resources (i.e., people, time, and money) are invested in:

a) specifying products, negotiations, ordering, and expediting activities

b) operational assets (IT, website, logistics) and functional systems integration (e.g., purchasing with IT)

c) establishing and building personal relationships with individual suppliers

d) developing our organization's network relationships within our supply market(s) or wider purchasing system

7. Our communication with primary suppliers can be characterized as:

a) our organization using undifferentiated communications with all suppliers

b) our organization using technology to communicate with and possibly among many individual suppliers

c) individuals at various levels in our organization personally interacting with individual suppliers

d) senior managers networking with other managers from a variety of organizations in our supply market(s) or wider purchasing system

8. When people from our organization meet with our primary suppliers, it is:

a) mainly at a formal business level

b) mainly at a formal level, yet customized and / or personalized via interactive technologies

c) at both a formal business level and informal social level on a one-to-one basis

d) at both a formal business level and informal social level in a wider organizational system / network

9. Overall, our organization's general approach to our primary suppliers (of product-related items) involves:

a) using aggressive sourcing (continuously search for new suppliers) to obtain purchase items at the most favorable conditions

b) using the Internet and other interactive technologies to create / mediate data exchange between our organization and our suppliers

c) developing personal interactions between employees and individual suppliers

d) positioning our organization in a wider organizational system / network

\section{Part 4}

This section has one question about how purchasing is practiced in your organization with your secondary suppliers (i.e., suppliers of non-product-related items).

Please answer all parts of the question by circling the number that best corresponds to what actually happens in your organization. The scale is a 5-point scale with 1 for 'never' and 5 for 'always.'

1. Overall, our organization's general approach to our secondary suppliers (of non-product-related items) involves...

a) using aggressive sourcing (continuously search for new suppliers) to obtain purchase items at the most favorable conditions

b) using the Internet and other interactive technologies to create / mediate data exchange between our organization and our suppliers

c) developing personal interactions between employees and individual suppliers

d) positioning our organization in a wider organizational system / network 
Part 5 (over the last year)

How has your organization performed relative to expectations for.... (the scale is a 5-point scale with 1 for 'much worse' and 5 for 'much better')
a) retaining current customers
b) gaining new customers
c) achieving customer satisfaction
d) attaining desired sales growth
e) securing desired market share
f) attaining desired profitability
g) improving supplier lead time
h) achieving supplier on-time delivery
i) securing supplier delivery reliability
j) improving supplier quality

\section{Part 6}

1. What is the title of your position?

2. How many years and months have you held this position?

3. How many years and months have you worked in your organization?

4. Would you describe your current position as purchasing related? Yes/No

5. Do you have any formal purchasing qualifications or purchasing training? Yes/No

6. What is the title of the most senior purchasing position in your organization?

7. What is your gender? Male/Female

8. How old are you? 


\section{Appendix B: Methodology}

\section{Checks of Data Quality}

The assessment of nonresponse bias relied on a comparison of the demographics of the respondents with the demographic make-up of all ISM members, ${ }^{\text {cviii }}$ which reveals that respondents are typical of ISM organizations. A time-trend extrapolation test can compare early and late responses on the key constructs; there were no significant differences. Nonresponse bias thus is not likely a problem in this study. ${ }^{\text {cix }}$

Because the measures all rely on a single source, common method bias in self-reported measures could be a concern. Employing the widely used Harman's one-factor method, ${ }^{\mathrm{cx}}$ a factor analysis was run on all measures to examine the likelihood of a single or dominant factor. The unrotated and rotated (varimax) solutions show no evidence of a dominant common factor (13 factors had eigenvalues greater than 1.0; the first factor accounts for only 22 percent of variance). There is no indication that common method bias is a serious issue for this study.

\section{Psychometric Quality of the Purchasing Practices Measurement Instrument}

The indicators of the four purchasing practices constructs are treated as formative, because each indicator describes a different facet of the latent construct. ${ }^{\text {cxi }}$ In other words, transaction purchasing, electronic purchasing, interactive purchasing, and network purchasing each result from a unique combination of indicators. Changes to one indicator are not necessarily associated with changes to the others. ${ }^{\text {cxii }}$ Although the indicators likely are correlated, they will not be highly correlated. For example, an organization's emphasis on transaction purchasing would be stronger if the organization were to increase its focus on achieving cost savings ("find the best deal"), even if it did not change its type of communication or contact with its direct supplier. 
To verify the psychometric properties of the measurement instrument, the four critical steps are followed that Diamantopoulos and Winklhofer propose for constructing indexes based on formative indicators: content specification, indicator specification, indicator collinearity, and external validity. ${ }^{\text {cxiii }}$ These authors propose two methods for testing the validity of formative measures: the method used in the present study, which also is widely used in management studies, ${ }^{\text {cxiv }}$ and the method that relies on structural equation modeling (MIMIC model). The latter method cannot be used in the present study, which neither hypothesizes causal relationships between the formative constructs nor includes reflective indicators. Also, MIMIC models often require a larger sample size.

Content specification. The classification of purchasing into transaction purchasing, electronic purchasing, interactive purchasing, and network purchasing and the development of formative indicators of the exchange and managerial aspects of purchasing appear in our theoretical background section. All practices and indicators have been identified in prior literature and confirmed by purchasing professionals and academics.

Indicator specification. Unlike reflective indicators, formative indicators must cover all aspects of the construct. ${ }^{\mathrm{cxv}}$ The methodology used to develop the framework of marketing practices, which is similar in its purpose to the purchasing practices framework, is studied and a literature review is conducted to identify purchasing practices and their indicators. Discussions with experienced purchasing professionals and academics helped validate the practices and indicators. This method offered confidence that the indicators effectively describe the exchange and managerial aspects of transaction purchasing, electronic purchasing, interactive purchasing, and network purchasing.

Indicator collinearity. Indicators in formative constructs are not interchangeable. If an indicator represents an almost perfect linear combination of the other indicators, it contains redundant information and does not measure a different aspect of the latent construct. ${ }^{\text {cxvi }}$ To 
test for collinearity, a variance inflation factor (VIF) was calculated per type of practice for each indicator $\left(\mathrm{VIF}_{\mathrm{ij}}=1 /\left[1-\mathrm{R}_{\mathrm{ij}}{ }_{\mathrm{ij}}\right.\right.$, where $\mathrm{R}_{\mathrm{ij}}{ }_{\mathrm{ij}}$ is the coefficient of determination for the prediction of variable $\mathrm{ij}$ by the other indicators of practice $\mathrm{j}^{\text {cxvii }}$ ). Most VIFs are below 2.0, and the largest VIF is 2.8 (network purchasing, managerial investment indicator). Therefore, all VIFs are below the conservative VIF threshold of $3.3^{\text {cxviii }}$ and considerably below 10 , the recommended cut-off value, ${ }^{\text {cxix }}$ and there is no evidence of excessive indicator collinearity.

External validity. To determine the external validity of the indicators for each purchasing practice construct, a global indicator was used that summarizes the essence of the construct as an external criterion - that is, the organization's general approach to direct suppliers. Each indicator of a particular practice should be correlated with the global indicator of that same practice. ${ }^{\text {cxx }}$ Bivariate correlation analysis shows that all indicators are highly significantly and positively correlated with their respective external criterion $(p<.02$ or better). These withinpractice correlations are marked in bold in Table A1.

Table A1 also shows that the indicators tend to be more highly correlated with their respective global indicator than with any other external global indicator (i.e., within-practice correlations higher than across-practice correlations), which confirms the quality of the measurement instrument. The only three exceptions are type of contact, indicator of transaction purchasing, and managerial intent and purpose of exchange, both indicators of electronic purchasing, but their correlations with the global indicator are still fine in terms of their size and significance (Table A1). There is no reason, theoretical or statistical, ${ }^{\text {cxxi }}$ to delete these two indicators from further analysis.

Thus, for each of the four practices, the organization's scores on eight indicators for that practice - purpose of exchange, managerial intent, nature of communication, type of contact, duration of exchange relationship, formality of exchange, managerial focus, and managerial investment-are summed and converted into an index, theoretically ranging from .2 to 1 . As 
final evidence for the external validity of our formative constructs the correlation between the index and the external criterion was computed. Correlations range between .601 and .805 , which indicates proper external validity. ${ }^{\text {cxxii }}$

\title{
Insert Table A1 about here
}

\begin{abstract}
i J.H. Dyer, C. Dong Sung, and W. Chu, "Strategic Supplier Segmentation: The Next 'Best Practice' in Supply Chain Management," California Management Review, 40/2 (Winter 1998): 57-77; R. Terpend, B.B. Tyler, D.R. Krause, and R.B. Handfield, "Buyer-Supplier Relationships: Derived Value over Two Decades," Journal of Supply Chain Management, 44/2 (April 2008): 28-55.

ii I.P. Morgan, "The Purchasing Revolution,” McKinsey Quarterly (Spring 1987): 49-55.

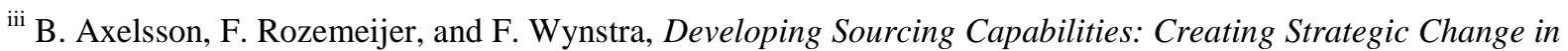
Purchasing and Supply Management (New York, NY: John Wiley \& Sons, 2005).

${ }^{\text {iv }}$ J. Westling, I. Fine, and G. Zenz, Purchasing Management: Materials in Motion (New York, NY: John Wiley \& Sons, 1969).

v R.B. Handfield, G.L. Ragatz, K.J. Petersen, and R.M. Monczka, "Involving Suppliers in New Product Development," California Management Review, 42/1 (Fall 1999): 59-82; M. Leenders, P. Fraser Johnson, A. Flynn, and H.E. Fearon, Purchasing and Supply Management, 13th ed. (Maidenhead: McGraw-Hill, 2006).

${ }^{v i}$ G.L. Frazier, R.E. Spekman, and C.R. O’Neal, “Just-in-Time Exchange Relationships in Industrial Markets," Journal of Marketing, 52/4 (October 1988): 52-67; J.K. Liker and Th.Y. Choi, "Building Deep Supplier Relationships," Harvard Business Review, 82/12 (December 2004): 104-113; Morgan, op. cit.

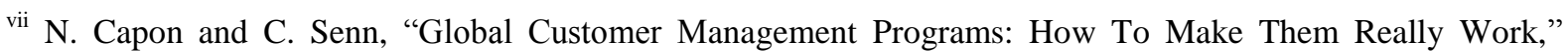
California Management Review, 52/2 (Winter 2010): 32-55; J.H. Dyer and H. Singh, "The Relational View: Cooperative Strategy and Sources of Interorganizational Competitive Advantage," Academy of Management Review, 23/4 (October 1998): 660-679; S. Janda and S. Seshadri, "The Influence of Purchasing Strategies on Performance,” Journal of Business \& Industrial Marketing, 16/4 (2001): 294-306.
\end{abstract}

viii M.A. Cusumano and A. Takeishi, A., "Supplier Relations and Management: A Survey of Japanese, JapaneseTransplant, and U.S. Auto Plants," Strategic Management Journal, 12/8 (November 1991): 563-588; J.H. Dyer and K. Nobeoka, "Creating and Managing a High-Performance Knowledge-Sharing Network: The Toyota Case," Strategic Management Journal, 21/3 (March 2000): 345-367; T. Nishiguchi and J. Brookfield, "The Evolution of Japanese Subcontracting," Sloan Management Review, 39/1 (Fall 1997): 89-101.

${ }^{\text {ix }}$ C.J. Corbett, J.D. Blackburn, and L.N. Van Wassenhove, "Partnerships to Improve Supply Chains," Sloan Management Review, 40/4 (Summer 1999): 71-82; F. Von Corswant and P. Fredriksson, "Sourcing Trends in the Car Industry: A Survey of Car Manufacturers' and Suppliers' Strategies and Relations," International Journal of Operations \& Production Management, 22/7-8 (July-August 2002): 741-758; W. Ulaga and A. Eggert, "Value-Based Differentiation in Business Relationships: Gaining and Sustaining Key Supplier Status," Journal of Marketing, 70/1 (January 2006): 119-36.

${ }^{x}$ B. Axelsson and F. Wynstra, Buying Business Services (Chichester: John Wiley \& Sons, 2002); Capon and Senn, op. cit.; L.-E. Gadde and H. Håkansson, Supply Network Strategies (New York: John Wiley \& Sons, 2001); S.R. Helper, "How Much has Really Changed Between US Automakers and Their Suppliers?" Sloan Management Review, 32/4 (Summer 1991): 15-28.

${ }^{x i}$ S.D. Jap and J.J. Mohr, "Leveraging Internet Technologies in B2B Relationships," California Management Review, 44/4 (Summer 2002): 24-38.

xii For example, see Capon and Senn, op. cit.; P.D. Cousins, B. Lawson, and B. Squire, "An Empirical Taxonomy of Purchasing Functions," International Journal of Operations \& Production Management, 26/7 (July 2006): 775-94; A. Paulraj, I.J. Chen, and J. Flynn, "Levels of Strategic Purchasing: Impact on Supply Integration and Performance," Journal of Purchasing \& Supply Management, 12/3 (March 2006): 107-122.

xiii In this article, the term 'practices' refers to four theoretical purchasing practices (transaction purchasing, electronic purchasing, interactive purchasing, and network purchasing), as well as to how an organization goes 
about practicing purchasing (and this actual mix of the four purchasing practices is referred to as the organization's purchasing configuration).

xiv A.S. Carr and J.N. Pearson, "Strategically Managed Buyer-Supplier Relationships and Performance Outcomes," Journal of Operations Management, $17 / 5$ (August 1999): 497-519; Paulraj et al., op. cit.

${ }^{x v}$ B.M. Bensaou, "Portfolios of Buyer-Supplier Relationships," Sloan Management Review, $40 / 4$ (Summer 1999): 35-44; S.D. Jap, "Pie-Expansion Efforts: Collaboration Processes in Buyer-Supplier Relationships," Journal of Marketing Research, 36/4 (November 1999): 461-475; P. Kraljic, "Purchasing Must Become Supply Management," Harvard Business Review, $61 / 5$ (September-October 1983): 109-117.

${ }^{\text {xvi }}$ R. Terpend, D.R. Krause, and K.J. Dooley, "Managing Buyer-Supplier Relationships: Empirical Patterns of Strategy Formulation in Industrial Purchasing," Journal of Supply Chain Management, 47/1 (January 2011): 7394.

${ }^{x v i i}$ N. Gil, "Developing Cooperative Project Client-Supplier Relationships: How Much to Expect from Relational Contracts," California Management Review, 51/2 (Winter 2009): 144-169; S. Tadelis, "A Tribute to Oliver Williamson: Williamson's Contribution and its Relevance to 21st Century Capitalism," California Management Review, 52/2 (Winter 2010): 159-166.

xviii Carr and Pearson, 1999, op. cit.; D.A. Johnston, D.M. McCutcheon, F.I. Stuart, and H. Kerwood, "Effects of Supplier Trust on Performance of Cooperative Supplier Relationships," Journal of Operations Management, 22/1 (February 2004): 23-38; M.A.M. Primo and S.D. Amundson, "An Exploratory Study of the Effects of Supplier Relationships on New Product Development Outcomes," Journal of Operations Management, 20/1 (February 2002): 33-52.

xix P.D. Cousins, "A Conceptual Model for Managing Long-Term Inter-Organisational Relationships," European Journal of Purchasing and Supply Management, 8/2 (2002): 71-82; L.-E. Gadde and I. Snehota, "Making the Most of Supplier Relationships," Industrial Marketing Management, 29/4 (July 2000): 305-316.

${ }^{\mathrm{xx}}$ Bensaou, op. cit.; J.B. Heide, "Interorganizational Governance in Marketing Channels," Journal of Marketing, 58/1 (January 1994): 71-85; Kraljic, op. cit.

${ }^{x x i}$ R.J. Brodie, N.E. Coviello, and H. Winklhofer, "Contemporary Marketing Practices Research Program: A Review of the First Decade,” Journal of Business \& Industrial Marketing, 23/2 (2008): 84-94. See p. 91.

${ }^{x x i i}$ N.E. Coviello, R.J. Brodie, P.J. Danaher, and W.J. Johnston, "How Firms Relate to Their Markets: An Empirical Examination of Contemporary Marketing Practices," Journal of Marketing, 66/3 (July 2002): 33-46; N.E. Coviello, R. Milley, and B. Marcolin, "Understanding IT-Enabled Interactivity in Contemporary Marketing," Journal of Interactive Marketing, 15/4 (Autumn 2001): 18-33.

xxiii Cousins et al., op. cit.; V.T. Freeman and J.L. Cavinato, "Fitting Purchasing to the Strategic Firm: Frameworks, Processes, and Values," Journal of Purchasing and Materials Management, 26/1 (Winter 1990): 6-10; R.F. Reck and B.G. Long, "Purchasing: A Competitive Weapon," Journal of Purchasing and Materials Management, 24/3 (Fall 1988): 2-8.

${ }^{x x i v}$ M. Christopher, Logistics and Supply Chain Management, 3rd ed. (London: Financial Times Series, 2004); D.M. Lambert and M.C. Cooper, "Issues in Supply Chain Management," Industrial Marketing Management, 29/1 (January 2000): 65-83; R.C. Lamming, T. Johnsen, J. Zheng, and C.M. Harland, "An Initial Classification of Supply Networks," International Journal of Operations \& Production Management, 20/6 (June 2000): 675691; R.C. McNally and A. Griffin, "A Measure and Initial Test of Managers' Perceptions of Relationship Marketing in Inter-Organizational Exchanges," Journal of the Academy of Marketing Science, 35/3 (September 2007): 382-397.

${ }^{\mathrm{xxv}}$ V. Kapoor and A. Gupta, “Aggressive Sourcing: A Free-Market Approach,” Sloan Management Review 39/1 (Fall 1997): 21-31.

${ }^{x x v i}$ G. Lorenzoni and A. Lipparini, "The Leveraging of Interfirm Relationships as a Distinctive Organizational Capability: A Longitudinal Study,” Strategic Management Journal 20/4 (April 1999): 317-338.

xxvii S.R. Croom, "The Impact of e-Business on Supply Chain Management: An Empirical Study of Key Developments," International Journal of Operations \& Production Management, 25/1 (January 2005): 55-73; G.T. Gundlach, Y.A. Bolumole, R.A. Eltantawy, and R. Frankel, "The Changing Landscape of Supply Chain Management, Marketing Channels of Distribution, Logistics and Purchasing," Journal of Business \& Industrial Marketing, 21/7 (2006): 428-438; C.P. Holland, "Cooperative Supply Chain Management: The Impact of Interorganizational Information Systems,” Journal of Strategic Information Systems, 4/2 (June 1995): 117-133; 
R.L. Stump and V. Sriram, "Employing Information Technology in Purchasing: Buyer-Supplier Relationships and Size of the Supplier Base,” Industrial Marketing Management, 26/2 (March 1997): 127-136.

xxviii D.J. Bowersox and P.J. Daugherty, "Emerging Patterns of Logistical Organization," Journal of Business Logistics, 8/1 (Summer 1987): 46-59; I.D. Ford, "The Development of Buyer-Seller Relationships in Industrial Markets," European Journal of Marketing, 14/5-6 (May-June 1980): 339-354; R. Landeros and R.M. Monczka, "Cooperative Buyer/Seller Relationships and a Firm's Competitive Posture," Journal of Purchasing and Materials Management, 25/3 (Fall 1989 ): 9-18.

${ }^{\text {xxix }}$ L. De Boer, J. Harink, and G. Heijboer, "A Conceptual Model for Assessing the Impact of Electronic Procurement," European Journal of Purchasing and Supply Management, 8/1 (March 2002): 25-33.

${ }^{x x x}$ S.D. Jap, “Online Reverse Auctions: Issues, Themes, and Prospects for the Future," Journal of the Academy of Marketing Science, 30/4 (Fall 2002): 506-25.

xxxi Jap and Mohr, op. cit.; A. Paulraj and I.J. Chen, "Strategic Buyer-Supplier Relationships, Information Technology and External Logistics Integration," Journal of Supply Chain Management, 43/2 (Spring 2007): 214.

xxxii D.N. Burt, D.W. Dobler, and S. Starling, World Class Supply Management: The Key to Supply Chain Management, 7th ed. (Boston, MA: McGraw-Hill, 2003); Jap and Mohr, op. cit.; Landeros and Monczka, op. cit.; M.J. Maloni and W.C. Benton, "Supply Chain Partnerships: Opportunities for Operations Research," European Journal of Operational Research, 101/3 (November 1997): 419-429; Terpend et al., 2011, op. cit.

xxxiii Bensaou, op. cit.; L.M. Ellram and O.R.V. Edis, "A Case Study of Successful Partnering Implementation," International Journal of Purchasing and Materials Management, 32/4 (Fall 1996): 20-28; Landeros and Monczka, op. cit.; R.E. Spekman, "Strategic Supplier Selection: Understanding Long-Term Buyer Relationships," Business Horizons, 31/4 (July 1988): 75-81.

${ }^{\text {xxxiv }}$ Croom, op. cit.; De Boer et al., op. cit.; Holland, op. cit.

${ }^{\mathrm{xxxv}}$ Gadde and Snehota, op. cit.; Spekman, op. cit.

${ }^{\text {xxxvi }}$ Christopher, op. cit.; Corbett et al., op. cit.

xxxvii B.B. Jackson, "Build Customer Relationships that Last," Harvard Business Review, 63/6 (NovemberDecember 1985): 120-128; Landeros and Monczka, op. cit.; Spekman, op. cit.

xxxviii Landeros and Monczka, op. cit.; Maloni and Benton, op. cit.

${ }^{\text {xxxix }}$ Bensaou, op. cit.; Cousins, op. cit.; Landeros and Monczka, op. cit.; T. B. Lawrence, E.A. Morse, and S.W. Fowler, "Managing Your Portfolio of Connections." Sloan Management Review, 46/2 (Winter 2005): 59-65; J. Mohr and J.R. Nevin, "Communication Strategies in Marketing Channels: A Theoretical Perspective," Journal of Marketing, 54/4 (October 1990): 36-51.

${ }^{\mathrm{xl}}$ Gadde and Håkansson, op. cit.

xli G. Lorenzi and C. Baden-Fuller, "Creating a Strategic Center to Manage a Web of Partners," California Management Review, 37/3 (Spring 1995): 146-163.

xlii Bensaou, op. cit.

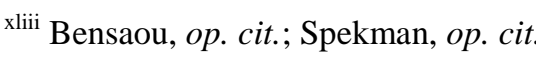

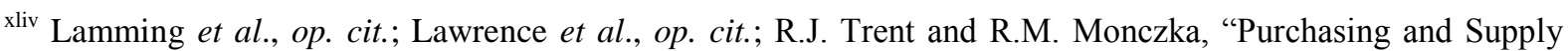
Management: Trends and Changes Throughout the 1990s," International Journal of Purchasing and Materials Management, 34/4 (Fall 1998): 2-11.

${ }^{x l v}$ Landeros and Monczka, op. cit.



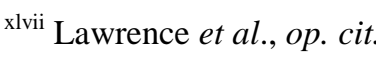

xlviii Holland, op. cit.; D.B. Holm, K. Eriksson, and J. Johanson, "Creating Value Through Mutual Commitment to Business Network Relationships," Strategic Management Journal, 20/5 (May 1999): 467-486; Landeros and Monczka, op. cit.

${ }^{\text {xlix }}$ Landeros and Monczka, op. cit.; Matthyssens and Van den Bulte, op. cit. 


\footnotetext{
${ }^{1}$ Spekman, op. cit.

li Trent and Monczka, op. cit.

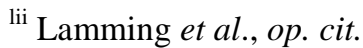

liii Bensaou, op. cit.

liv M. Naim, S. Disney, and D. Towill, "Supply Chain Dynamics," In S. New and R. Westbrook (Eds.), Understanding Supply Chains: Concepts, Critiques, and Futures (Oxford: Oxford University Press, 2004): 109132.

lv Landeros and Monczka, op. cit.; F.I. Stuart, "Supplier Partnerships: Influencing Factors and Strategic Benefits," International Journal of Purchasing and Materials Management, 29/4 (Fall 1993): 22-28.
}

${ }^{\text {lvi }}$ Of the 256 questionnaires returned, 151 (59.0\%) arrived through regular mail, and 105 (41.0\%) were completed online. A multivariate analysis of variance (MANOVA) of the 40 purchasing practice items showed no significant differences related to response method $(\mathrm{F}(36,160)=.801, p=.512)$, so all the responses may be pooled. The main reasons for nonparticipation were that the organization no longer trades, company policy did not allow survey participation, the respondent was no longer working for the organization, or the respondent lacked time to complete the relatively long questionnaire. The 54 questionnaires with substantial missing data were excluded from further analysis, so the final analysis used 202 organizations (effective response rate: $6.1 \%$ ). The relatively low response rate is not unusual in supply management studies (see references A), and the absolute number of usable responses compares favorably to other studies in this area (see references B). References A: Y. Dong, C.R. Carter, and M.E. Dresner, "JIT Purchasing and Performance: An Exploratory Analysis of Buyer and Supplier Perspectives,” Journal of Operations Management, 19/4 (July 2001): 471-483; S.B. Modi and V.A. Mabert, "Supplier Development: Improving Supplier Performance Through Knowledge Transfer," Journal of Operations Management, 25/1 (January 2007): 42-64; K.C. Tan, S.B. Lyman, and J.D. Wisner, "Supply Chain Management: A Strategic Perspective," International Journal of Operations \& Production Management, 22/5-6 (May-June 2002): 614-631. References B: J. Gonzalez-Benito, "A Theory of Purchasing's Contribution to Business Performance," Journal of Operations Management, 25/4 (June 2007): 901-917; M. Howard and B. Squire, "Modularization and the Impact on Supply Relationships," International Journal of Operations \& Production Management, 27/11 (November 2007): 1192-1212; Tan et al., op. cit.; S.K. Vickery, J. Jayaram, C. Dröge, and R. Calantone, "The Effects of an Integrative Supply Chain Strategy on Customer Service and Financial Performance: An Analysis of Direct versus Indirect Relationships," Journal of Operations Management, 21/5 (December 2003): 523-539.



lviii Jap and Mohr, op. cit.; Leenders et al., op. cit.; R. Monczka, R. Trent, and R. Handfield, Purchasing and Supply Chain Management, 3rd ed. (Mason, OH: South-Western, 2005).

${ }^{\text {lix }}$ Coviello et al., 2002, op. cit.

${ }^{1 x}$ A. Cox, D. Chicksand, P. Ireland, and T. Davies, "Sourcing Indirect Spend: A Survey of Current Internal and External Strategies for Non-Revenue-Generating Goods and Services," Journal of Supply Chain Management, 41/2 (Spring 2005): 39-51; L.M. Ellram, W.L. Tate, and C. Billington, "Services Supply Management: The Next Frontier for Improved Organizational Performance," California Management Review, 49/4 (Summer 2007): 4466; Jap, op. cit.; Kapoor and Gupta, op. cit.; Monczka et al., op. cit.

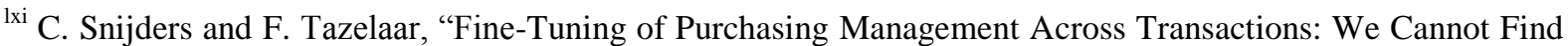
It: An Empirical Investigation into the Purchasing Management of 23 Dutch Firms," in R. Lamming (Ed.), Proceedings of the 16th Annual IPSERA Conference: Purchasing and Supply Research: Practice Makes Perfect (Bath University, Bath, 1-4 April 2007).

lxii As in Cousins et al., op. cit.

1xiii As recommended by J. Rossiter, "The C-OAR-SE Procedure for Scale Development in Marketing," International Journal of Research in Marketing, 19/4 (December 2002): 305-35, intensity-free Likert itemstems are used and the response intensity is built into the leaves of the item ('never' to 'always').

lxiv Scales adapted from T.C. Harrington, D.M. Lambert, and M. Christopher, "A Methodology for Measuring Vendor Performance," Journal of Business Logistics, 12/1 (Summer 1991): 83-104; and H. Shin, D.A. Collier, and D.D. Wilson, "Supply Management Orientation and Supplier-Buyer Performance," Journal of Operations Management, 18/3 (April 2000): 317-333. 
${ }^{1 x v}$ Marketing performance and financial performance scales both from Coviello et al., 2002, op. cit.


Strategies on Performance," Journal of Business \& Industrial Marketing, 16/4 (2001): 294-306.

${ }^{\text {Ixvii }}$ Shin et al., op. cit.

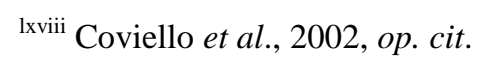

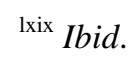

${ }^{1 x x}$ Pearson correlations between the different approaches show that electronic purchasing and interactive purchasing are significantly and positively correlated with network purchasing $(.688$ and $.655, p<.001)$ but not with transaction purchasing $(.081, p>.05)$; in addition, electronic purchasing and interactive purchasing significantly correlate with each other $(.444, p<.001)$. This result is consistent with Coviello et al.'s (2002) finding that interaction marketing correlates with transaction marketing but not significantly with network marketing.

Ixxi Axelsson and Wynstra, op. cit.; Carr and Pearson, 1999, op. cit.; Chen, I.J., A. Paulraj, and A.A. Lado, "Strategic Purchasing, Supply Management, and Firm Performance," Journal of Operations Management, 22/5 (October 2004): 505-523; Cusumano and Takeishi, op. cit.

Ixxii Bensaou, op. cit.; D.M. Lambert, M.A. Emmelhainz, and J.T. Gardner, "Developing and Implementing Supply Chain Partnerships," International Journal of Logistics Management, 7/2 (Winter 1996): 1-17; Liker and Choi, op. cit.

Ixxiii The variance inflation factors (VIFs) are below 2.0, except the transaction purchasing index, which is 2.9. These values are well below 10, the threshold limit, and confirm the absence of collinearity.

${ }^{\text {Ixxiv }}$ J.F. Hair, R.E. Anderson, R.L. Tatham, and W.C. Black, Multivariate Data Analysis, 5th ed. (Upper Saddle River, NJ: Prentice-Hall International, 1998).

lxxv Ibid.; M.T. Frohlich and R. Westbrook, "Arcs of Integration: An International Study of Supply Chain Strategies,” Journal of Operations Management, $19 / 2$ (February 2001): 185-200, op. cit.

${ }^{\text {lxxvi }}$ M.S. Aldenderfer and R.K. Blashfield, Cluster Analysis (London: Sage, 1984); P. Arabie and L. Hubert, "Cluster Analysis in Marketing Research," in R.P. Bagozzi (Ed.), Advanced Methods in Marketing Research, (Oxford: Blackwell, 1994): 160-89.

1xxvii Aldenderfer and Blashfield, op. cit.; Hair et al., op. cit.; R. Kathuria, "Competitive Priorities and Managerial Performance: A Taxonomy of Small Manufacturers," Journal of Operations Management, 18/6 (November 2000): 627-41.

Ixxviii This most likely number of clusters should lie between N/60 (or 3.5) and N/30 (or 6.5). See Kathuria, op. cit.

${ }^{\text {lxxix }}$ Aldenderfer and Blashfield, op. cit.

${ }^{1 \mathrm{xxx}}$ A relatively large increase would imply that dissimilar clusters merged together in step $\mathrm{S}$, which means that the number of clusters at step $\mathrm{S}-1$ would be the most appropriate choice. See Hair et al., op. cit.

${ }^{1 \times x x i}$ Hair et al., op. cit.

${ }^{1 \times x x i i}$ Hair et al., op. cit.

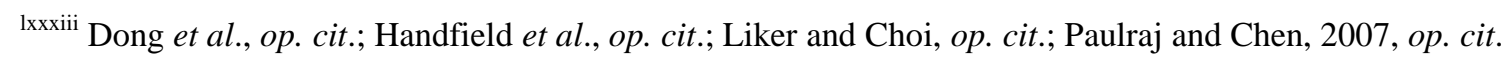

${ }^{\text {Ixxxiv }}$ Shin et al., op. cit.

${ }^{1 x x x v}$ L.L. Stanley and J.D. Wisner, "Service Quality Along the Supply Chain: Implications for Purchasing," Journal of Operations Management, 19/3 (May 2001): 287-306.


Journal of Marketing, 52/2 (April 1988): 1-20; Stanley and Wisner, op. cit.; J.W. Stoelhorst and E.M. Van Raaij, "On Explaining Performance Differentials: Marketing and the Managerial Theory of the Firm," Journal of Business Research, 57/5 (May 2004): 462-477.

${ }^{\text {Ixxxvii }}$ Carr and Pearson, 1999, op. cit.; Chen et al., op. cit.; Gonzalez-Benito, op. cit.; Paulraj et al., 2006, 2007, op. cit.; A.S. Carr and J.N. Pearson, "The Impact of Purchasing and Supplier Involvement on Strategic 
Purchasing and Its Impact on Firm's Performance," International Journal of Operations \& Production Management, 22/9-10 (September-October 2002): 1032-1053.

Ixxxviii These results were based on a MANOVA with cluster membership as a between-subjects factor $(\mathrm{F}(30$, $516)=1.578, p<.05$ ), followed by a contrast analysis (one-tail tests), which revealed the statistical significance of the hypothesized differences. See Hair et al., op. cit. Directional (one-tailed) tests are used because, based upon the literature, a higher score is hypothesized for the relational integrative configuration compared to the other configurations. See G.A. Churchill, Marketing Research: Methodological Foundations, 7th ed. (Orlando, FL: The Dryden Press, 1999) for a discussion of one-tailed and two-tailed tests.

lxxxix These results are based on analyses of variance (ANOVAs) for the level of technology intensity $(\mathrm{F}(3,198)$ $=10.304, p<.001)$ and the role of technology $(\mathrm{F}(3,197)=5.805, p<.001)$, as well as post hoc difference tests (differences were significant at $p<.05$ ). Two-tailed post hocs tests are used because we merely explored the possible existence of differences across means for these variables (see previous note).

${ }^{\mathrm{xc}}$ Using the four global indicators for both direct and indirect suppliers, a MANOVA used the type of supplier as a within-subjects factor and cluster membership as a between-subjects factor. Significant differences arose between direct and indirect suppliers in terms of purchasing practices $(\mathrm{F}(4,188)=14.257, p=.0001)$. The significance levels of the univariate ANOVAs for TP, IP, and NP ranged from .000 to .007.

${ }^{\text {xci }}$ Paulraj et al., 2006, op. cit.; Carr and Pearson, 1999, op. cit.

${ }^{\text {xcii }}$ See Cox et al., op. cit., Ellram et al., op. cit., Jap, op. cit., Kapoor and Gupta, op. cit., and Leenders et al., op. cit. for theoretical elements discussed in this paragraph.

xciii N.P. Greis and J.D. Kasarda, "Enterprise Logistics in the Information Era," California Management Review, 39/4 (Summer 1997): 55-78..

${ }^{\text {xciv }}$ B.R. Konsynski, "Strategic Control in the Extended Enterprise," IBM Systems Journal, 32/1 (Spring 1993): 111-42. See p. 112.

${ }^{x c v}$ S. Sivadasan, J. Efstathiou, A. Calinescu, and L.H. Huatuco, "Supply Chain Complexity." In S. New and R. Westbrook (Eds.), Understanding Supply Chains: Concepts, Critiques, and Futures (Oxford: Oxford University Press, 2004), 133-163.

${ }^{x c v i}$ R.M. Morgan and S.D. Hunt, S.D., “The Commitment-Trust Theory of Relationship Marketing," Journal of Marketing, 58/3 (July 1994): 20-38; B. Nooteboom, Trust: Forms, Foundations, Functions, Failures and Figures (Cheltenham: Edward Elgar, 2002).

xcvii R. Spekman and E. Davis, "Risky Business: Expanding the Discussion on Risk and the Extended Enterprise," International Journal of Physical Distribution \& Logistics Management, 34/5 (2004): 414-433; J.M. Whipple, D.F. Lynch, and G.N. Nyaga, "A Buyer's Perspective on Collaborative versus Transactional Relationships,” Industrial Marketing Management, 39/3 (April 2010): 507-518.

xcviii C. Baier, E. Hartmann, and R. Moser, "Strategic Alignment and Purchasing Efficacy: An Exploratory Analysis of their Impact on Financial Performance," Journal of Supply Chain Management, 44/4 (September 2008): 36-52; Chen et al., op. cit.

${ }^{x c i x}$ The minimum sample size for cluster analysis is at least $2^{\mathrm{m}}$, where $\mathrm{m}$ equals the number of clustering variables, that is, 4 in our case; $5 * 2^{\mathrm{m}}$ is, however, the ideal situation (see Forman (1984), cited in Dolnicar, S. (2003), "Using Cluster Analysis for Market Segmentation: Typical Misconceptions, Established Methodological Weaknesses and Some Recommendations for Improvement," Australasian Journal of Market Resesarch, 11/2 (November 2003): 5-12 and E. Mooi and M. Sarstedt, M., A Concise Guide to Market Research (Heidelberg: Springer, 2011).

c See, for example, S. Kulp, T. Randall, G. Brandyberry, and K. Potts, "Using Organizational Control Mechanisms to Enhance Procurement Efficiency: How GlaxoSmithKline Improved the Effectiveness of EProcurement," Interfaces, 36/3 (May/June 2006): 209-219, with an example of 49 sourcing categories for one organization.

${ }^{\text {ci }}$ Axelsson and Wynstra, op. cit.; Gadde and Snehota, op. cit.; Helper, op. cit..

cii C. Steinle and H. Schiele, "Limits to Global Sourcing? Strategic Consequences of Dependency on International Suppliers: Cluster Theory, Resource-Based View and Case Studies," Journal of Purchasing and Supply Management, 14/1 (January 2008): 3-14. 
ciii Coviello et al., 2002, op. cit.; D. Narayandas and V.K. Rangan, "Building and Sustaining Buyer-Seller Relationships in Mature Industrial Markets,” Journal of Marketing, 68/3 (July 2004): 63-77.

civ Beverland, M.B. and Lindgreen, A., "Relationship Use and Market Dynamism: A Model of Relationship Evolution," Journal of Marketing Management, 20/7-8 (July-August 2004): 825-858; R.F. Dwyer, P.H. Schurr, and S. Oh, "Developing Buyer and Seller Relationships," Journal of Marketing, 51/2 (April 1987): 11-27; M.K. Hingley, "Power to All Our Friends? Living With Imbalance in Supplier-Retailer Relationships," Industrial Marketing Management, 34/8 (November 2005): 848-858.

${ }^{c v}$ Bowersox and Daugherty, op. cit.; Terpend et al., 2008, op. cit; P.F. Johnson, M.R. Leenders, and H.E. Fearon, "Evolving Roles and Responsibilities of Purchasing Organizations," International Journal of Purchasing and Materials Management, 34/1 (Winter 1998): 2-11.

${ }^{\text {cvi }}$ P.A. Dabholkar, W.J. Johnston, and A.S. Cathey, "The Dynamics of Long-Term Business-to-Business Exchange Relationships," Journal of the Academy of Marketing Science, 22/2 (Spring 1994): 130-145.

${ }^{\text {cvii }}$ Frohlich and Westbrook, op. cit.; C. Claycomb and G.L. Frankwick, "Buyers' Perspectives of Buyer-Seller Relationship Development," Industrial Marketing Management, 39/2 (February 2010): 252-63.

cviii ISM, ISM Membership Demographics (Tempe, AZ: Institute for Supply Management, 2004).

cix J.S. Armstrong and T.S. Overton, "Estimating Non-Response Bias in Mail Services," Journal of Marketing Research, 14/3 (June 1977): 396-402.

cx A.S. Carr and H. Kaynak, "Communication Methods, Information Sharing, Supplier Development and Performance: An Empirical Study of Their Relationships," International Journal of Operations \& Production Management, 27/4 (April 2007): 346-370; Gonzalez-Benito, op. cit.; Howard and Squire, op. cit.; Paulraj et al., 2006, ор. cit.; P.M. Podsakoff and D.W. Organ, "Self-Reports in Organizational Research: Problems and Prospects," Journal of Management, $12 / 4$ (Winter 1986): 531-44. The amount of common method variance is an issue when either a single factor emerges from the factor analysis or one general factor accounts for the majority of covariance among the measures.

${ }^{\text {cxi }}$ A. Diamantopoulos and H.M. Winklhofer, "Index Construction with Formative Indicators: An Alternative to Scale Development," Journal of Marketing Research, 38/2 (May 2001): 269-277; Rossiter, op. cit. It should be noted that the formative measurement approach has gained increased attention in response to arguments that measures treated as reflective in many empirical management studies probably have been misspecified. See for example A. Diamantopoulos and J.A. Siguaw, "Formative Versus Reflective Indicators in Organizational Measure Development: A Comparison and Empirical Illustration," British Journal of Management, 17/4 (December 2006): 263-282; Rossiter, op. cit. Because knowledge of formative measures is relatively less advanced though, the debate regarding their properties, advantages, and limitations continues. See J.B. Wilcox, R.D. Howell, and E. Breivik, E. (2008). "Questions about Formative Measurement," Journal of Business Research, 61/12 (December 2008): 1219-1228. One of the most controversial issues remains the appropriate validity assessement of formative measures. See A. Diamantopoulos, P. Riefler, and K.P. Roth, "Advancing Formative Measurement Models,” Journal of Business Research, 58/12 (December 2008): 1203-1218.

cxii Diamantopoulos and Winklhofer, op. cit.

cxiii Ibid.

cxiv See for example N. Coviello, H. Winklhofer, and K. Hamilton, "Marketing Practices and Performance of Small Service Firms: An Examination in the Tourism Accommodation Sector," Journal of Service Research, 9/1 (August 2006): 38-58; Ch. Homburg, O. Jensen, and H. Krohmer, "Configurations of Marketing and Sales: A Taxonomy," Journal of Marketing, 72/2 (March 2008): 133-154; C.S. Katsikeas, D. Skarmeas, and D.C. Bello, "Developing Successful Trust-Based International Exchange Relationships," Journal of International Business Studies, 40/1 (January 2009): 132-155; C. Nakata, Z. Zhu, and E. Izberk-Bilgin, "Integrating Marketing and Information Services Functions: A Complementarity and Competence Perspective," Journal of the Academy of Marketing Science, $39 / 5$ (October 2011): 700-716; C.B. Noordhoff, K. Kyriakopoulos, C. Moorman, P. Pauwels, and B.G.C. Dellaert, "The Bright Side and Dark Side of Embedded Ties in Business-toBusiness Innovation,” Journal of Marketing, $75 / 5$ (September 2011): 34-52; R.W. Palmatier, L.K. Scheer, M.B. Houston, K.R. Evans, and S. Gopalakrishna, "Use of Relationship Marketing Programs in Building CustomerSalesperson and Customer-Firm Relationships: Differential Influences on Financial Outcomes," International Journal of Research in Marketing, 24/3 (September 2007): 210-223; M.S. Salimath, J.B. Cullen, and U.N. Umesh, "Outsourcing and Performance in Entrepreneurial Firms: Contingent Relationships with Entrepreneurial Configurations,” Decision Sciences, 39/3 (August 2008): 337-358. 
${ }^{\mathrm{cxv}}$ Ibid.

cxvi Ibid.

${ }^{\text {cxvii }}$ Hair et al., op. cit.

cxviii Diamantopoulos and Siguaw, op. cit. All condition indices are also largely below 30, further confirming the absence of collinearity problems (Hair et al., op. cit.). Confirming that condition indeces are below 30 is a complementary check of dependence between indicators.

cxix Ibid.

${ }^{c x x}$ Diamantopoulos and Winklhofer, op. cit. The use of bivariate correlations is the standard approach for testing the external validity of indicators for formative measures (see Coviello et al., op. cit.; Katsikeas et al., op. cit.; Nakata et al., op. cit.; Noordhoff et al., op. cit.; Palmatier et al., op. cit.; Salimath et al., op. cit.).

${ }^{c x x i}$ Rossiter, op. cit. Note that the relatively small sample size might be the cause of these less clear patterns of correlations encountered in the present study. See also Palmatier et al., op. cit. and Katsikeas et al., op. cit.

cxxii J. Cohen, Statistical Power Analysis for the Behavioural Sciences, 2nd ed. (Hillsdale, NJ: Lawrence Erlbaum Associates, 1988). 